\title{
Increased Parasitic Load in Captive-Released European Bison (Bison bonasus) has Important Implications for Reintroduction Programs
}

\author{
Marta Kołodziej-Sobocińska(D, ${ }^{1}$ Aleksadner W. Demiaszkiewicz, ${ }^{2}$ Anna M. Pyziel, ${ }^{2}$ \\ and Rafał Kowalczyk ${ }^{1}$ \\ ${ }^{1}$ Mammal Research Institute, Polish Academy of Sciences, Stoczek 1, 17-230 Białowieza, Poland \\ ${ }^{2}$ W. Stefanski Institute of Parasitology, Polish Academy of Sciences, Warsaw, Poland
}

\begin{abstract}
Captive-bred animals, widely used in reintroduction programmes, are often immunologically naïve and more susceptible to pathogens. We analysed infection of invasive blood-sucking nematode Ashworthius sidemi in captive-bred European bison (Bison bonasus) released to the wild in the Białowieża Forest (Poland). Mean A. sidemi infection intensity of released bison (29,137 nematodes) was over threefold higher than in wild bison (8756). It indicates a rapid acquisition and increase in the infection intensity in previously dewormed bison released from captivity. Thus, reintroduction programmes should consider the impact of pathogens and involve controlled exposure of captive animals to specific parasites prior to release.
\end{abstract}

Keywords: Blood-sucking nematode, Ashworthius sidemi, Captive breeding, Conservation management, Immune response

Diseases play an important role in wild populations, strongly influencing their condition and demography (Scott 1988). They are often a real threat to rare and endangered species, whose survival is one of the main issues in conservation programmes (Pucek et al. 2004; Viggers et al. 1993). Captive-bred animals are often used in reintroduction programmes (Mathews et al. 2006; Tear et al. 1993), especially in rare species for which captive breeding is the most important source of individuals for release (Tear et al. 1993). Captive animals are regularly dewormed to prevent spread of parasitic diseases, and in most cases they have no prior contact with pathogens occurring in the wild and are very likely to be immunologically naïve and

Published online: March 16, 2018

Correspondence to: Marta Kołodziej-Sobocińska, e-mail: mksobocinska@ibs.bialowieza.pl more susceptible to pathogens present in the environment (Viggers et al. 1993). Host susceptibility to disease is influenced by several factors, including the following, among others: (1) population density (pathogen transmission, nutritional and social stress), (2) innate resistance and the ability of the host to mount an immune response and (3) the stress associated with reintroduction, which may increase pathological effects of infectious agents and further debilitate released animals (Viggers et al. 1993; Wakelin 1978). Thus, the importance of diseases and their impact on reintroduced animals should be taken into account in conservation and reintroduction programmes.

The European bison (Bison bonasus L., 1758) was extirpated in the wild at the beginning of twentieth century and later restored with captive survivors. There are now over 4000 European bison in the wild distributed between 
35 isolated populations (Raczyński 2015). Additionally, 2000 bison live in numerous breeding centres and zoos, which constitute an important source of individuals for reintroductions (Raczyński 2015). Bison are one of the main species in rewilding programmes in Europe, and there have been discussions on the need to establish new herds and create a more continuous distribution range (Kuemmerle et al. 2011). Apart from small herd size, isolation and low genetic variation due to a severe genetic bottleneck after extinction in the wild (Tokarska et al. 2011), diseases and parasites (Pucek et al. 2004) are the main threats to bison. Among the 88 parasite species discovered in European bison (Dróżdż et al. 1998; Karbowiak 2014a, b), the blood-sucking nematode Ashworthius sidemi is probably the most pathogenic. This parasite is specific to Asian deer species, especially sika deer (Cervus nippon) (Dróżdż et al. 1998) and was first found in bison from Białowieża Forest (BF) in 2000 (Kołodziej-Sobocińska et al. 2016a). Adult nematodes are located in abomasa of bison and other ruminants; eggs are shed with faeces. Bison get infected usually directly by ingestion of contaminated food (Dróżdż et al. 1998). Previous studies have shown the influence of herd size and winter bison aggregation on A. sidemi and coccidia infection (Kołodziej-Sobocińska et al. 2016a; Pyziel et al. 2011; Radwan et al. 2010) as well as on the seasonal pattern of parasite egg excretion (KołodziejSobocińska et al. 2016c).

In this study, we investigated the parasitic load of five captive-bred bison released into the wild and then culled after some time, compared with simultaneously studied 41 wild-born animals. We hypothesised that captive-bred bison are more susceptible to invasion because they have not acquired immunity to A. sidemi while living in captivity.

The study was conducted in BF, located on the PolishBelarusian border, which is inhabited by the largest freeliving bison population (over 500 bison in the Polish part of the forest). Bison is fully protected and endangered species. The bison population in $\mathrm{BF}$ has been regulated since the 1970s through culling or translocation (Krasińska and Krasiński 2013). Between 2002 and 2016, 57 culled bison males over 1 year old, including five bison released from captivity, 11 captive and 41 wild-born and free-living individuals, were parasitologically examined postmortem. Limited number of individuals released from captivity results from rarity of studied species, for which collection of larger samples is very difficult. The five bison released from captivity as subadults spent between 179 and 1485 days $(609 \pm 569$ on average) in the wild (Table 1) and were culled by Białowieża National Park (BNP) staff. As all the released bison were culled due to necrotic disease of the external genital organs (posthitis) (Jakob et al. 2000), the comparative group of wild bison also included males culled due to this disease. The entire contents of the abomasa of culled bison were examined according to Dróżdż et al. (1998). Nematode species were determined morphologically (Dróżdż et al. 1998), and the number of A. sidemi was counted.

Bison released from captivity had from 5504 to 77,630 A. sidemi nematodes per bison (Table 1); 29,137 $\pm 13,222$ on average. Their infection intensity was significant and over threefold higher than in wild bison (mean $8756 \pm 1418$; range $0-37,670 ; p=0.048 ; U=46.0$ ), and over 2000 times higher than in captive bison (mean $14.0 \pm 7.0$; range $0-67 ; p=0.0016 ; U=0.0$ ) (Fig. 1). The data suggest that bison released from captivity into the wild suffer a rapid increase in A. sidemi infection intensity.

Captive breeding programmes are often source of animals for release to supplement or re-establish endangered species populations to prevent their extinction, enrich their gene pool or establish new populations in the wild (Daszak et al. 2000; Faria et al. 2010). Factors that are taken into account in reintroduction programmes include usually: habitat suitability, animal behaviour and density, predators and competitors, the genetic issues, and considerable financial and human support to implement and monitor the programme for many years (Viggers et al. 1993). However, diseases and parasites can also play an important role (Cunningham 1996; Daszak et al. 2000; Schmidt-Posthaus et al. 2002; Viggers et al. 1993). This is because the reduced exposure to natural antigens and loss of immunogenetic variation during captive breeding may impair the survival probability of released animals (Cunningham 1996; Mathews et al. 2006; Viggers et al. 1993). Thus, the risk of diseases and mentioned above associated factors should be considered in the conservation programmes, especially for rare and endangered species. In our study, the animals released from captivity quickly gained a high parasitic load, much higher than wild animals of similar sex and age. This indicates high susceptibility of captive-bred and immunologically naïve individuals to parasitological infection (Cunningham 1996). A high infection level of $A$. sidemi leads to deterioration of red blood cell parameters, which may weaken bison and increase their susceptibility to other pathogens (KołodziejSobocińska et al. 2016b). As many natural populations tend to be held in long-term balance by host-pathogen inter- 




Fig. 1. Comparison of A. sidemi infection intensity in three European bison male groups in Białowieza Forest: captive, wild and released from captivity into the wild.

Table 1. Data of Bison Males Released from Captivity into the Wild in the Białowieża Primeval Forest, the Length of Their stay in the Wild and the Blood-Sucking Nematode A. sidemi Infection Intensity.

\begin{tabular}{lllllrr}
\hline $\begin{array}{l}\text { Bison } \\
\text { pedigree } \\
\text { number }\end{array}$ & $\begin{array}{l}\text { Age } \\
(\text { months })\end{array}$ & $\begin{array}{l}\text { Weight } \\
(\mathrm{kg})\end{array}$ & Date of birth and culling & Date of the release & $\begin{array}{l}\text { No. of } \\
\text { days spent } \\
\text { in the wild }\end{array}$ & $\begin{array}{l}\text { A. sidemi } \\
\text { number }\end{array}$ \\
\hline 9538 & 47 & 470 & 26th April 2001-9th March 2005 & 27th August 2004 & 194 & 23,790 \\
9541 & 45 & 460 & 12th May 2001-22nd February 2005 & 27th August 2004 & 179 & 5504 \\
10,772 & 30 & 280 & 25th June 2006-16th December 2008 & 19th February 2008 & 301 & 32,940 \\
10,773 & 66 & 560 & 18th September 2006-14th March 2012 & 19th February 2008 & 1485 & 5820 \\
11,010 & 69 & 370 & 22nd May 2005-2nd February 2011 & 1st September 2008 & 884 & 77,630 \\
\hline
\end{tabular}

actions (May 1988), acquisition of immunity to some diseases may require long-term and low-intensity exposure to pathogens (Wakelin 1978). Moreover, host susceptibility to disease may be influenced by population density which might increase pathogen transmission and social stress, innate resistance and the ability to mount an immune response (Radwan et al. 2010; Wakelin 1978). For example, the increased contact rate between bison in winter due to large aggregations arising from supplementary feeding in fixed locations promotes parasite transmission (Karbowiak et al. 2014b; Kołodziej-Sobocińska et al. 2016a; Pyziel et al. 2011; Radwan et al. 2010). The five bison released from captivity stayed in the places where supplementary feeding was intense, which further increased the number of parasites transmitted to these immunologically naïve individuals. Higher A. sidemi infection intensities were associated with longer stays of released bison in the wild, which suggests bison suffered repeat infections and insufficient immune responses.

Bison in captivity are regularly dewormed (Krzysiak et al. 2015), which is a standard procedure to avoid parasite transmission in captivity. However, treatment of animals prior to release may not be beneficial, because it may reduce their levels of immunity to disease (Faria et al. 2010; Viggers et al. 1993). This is especially important if such pathogens are present in wild populations, as is the case of bloodsucking nematode $A$. sidemi in the bison population in $\mathrm{BF}$ (Dróżdż et al. 1998; Kołodziej-Sobocińska et al. 2016a, c); regularly dewormed captive bison have no chance to acquire immunity against $A$. sidemi or other parasites that they come into contact with upon release. Moreover, release into the wild probably stresses bison, which could make them more 
susceptible to infection (Dickens et al. 2010). It has been proposed that when there are parasites present in wild populations to which captive animals have not been exposed, then it may be advisable to provide low-level exposure in captivity to develop some immunity (Viggers et al. 1993). Recently, since 2012, low A. sidemi infection intensity has been reported in captive bison (Kołodziej-Sobocińska et al. 2016b; Krzysiak et al. 2015). Hopefully, controlled exposure of animals to parasites prior to release may be beneficial and increase their immunity.

The impacts of disease have been neglected in mammal reintroduction programmes, including those involving European bison. Thus, the management protocols should be established and standardised for endangered species reintroductions. These would help to avoid hazards and prevent failure of the programmes caused by exposure to new diseases and weakening of naive individuals released from captivity. In recent years, European bison have been introduced to new places in Europe; by understanding the factors that can cause failure of bison reintroductions, we can design more optimal conservation management approaches. This would help to reduce the conservation risk though exposure of naive captive animals to pathogens present in the wild.

\section{ACKNOWLEDGEMENTS}

The study was financed by Polish National Science Centre, Project No. 2012/07/B/NZ8/00066. We would like to thank the Białowieza National Park staff for help in the collection of biological material and Tomasz Diserens for correcting the English in the manuscript.

\section{COMPLIANCE WITH ETHICAL STANDARDS}

CONFLICT OF INTEREST The authors declare no conflict of interest.

\section{Open Access}

This article is distributed under the terms of the Creative Commons Attribution 4.0 International License (http:// creativecommons.org/licenses/by/4.0/), which permits unrestricted use, distribution, and reproduction in any medium, provided you give appropriate credit to the original author(s) and the source, provide a link to the Creative Commons license, and indicate if changes were made.

\section{REFERENCES}

Cunningham AA (1996) Disease risks of wildlife translocations. El riesgo de la transmisión de enfermedades en las translocaciones de especies silvestres. Conservation Biology 10(2):349-353. https://doi.org/10.1046/j.1523-1739.1996.10020349.x

Daszak P, Cunningham AA, Hyatt AD (2000) Emerging infectious diseases of wildlife- threats to biodiversity and human health. Science 287(5452):443-449. https://doi.org/10.1126/science.287. 5452.443

Dickens MJ, Delehanty DJ, Romero LM (2010) Stress: an inevitable component of animal translocation. Biological Conservation 143(6):1329-1341. https://doi.org/10.1016/j.biocon.2010.02.032

Dróżdż J, Demiaszkiewicz AW, Lachowicz J (1998) Ashworthius sidemi (Nematoda, Trichostrongylidae) a new parasite of the European bison Bison bonasus (L.) and the question of independence of A. gagarini. Acta Parasitologica 43(2):75-80

Faria PJ, van Oosterhout C, Cable J (2010) Optimal release strategies for captive-bred animals in reintroduction programs: Experimental infections using the guppy as a model organism. Biol Conserv 143(1):35-41. https://doi.org/10.1016/j.biocon. 2009.06.002

Jakob W, Schröder HD, Rudolph M, Krasiński ZA, Krasińska M, Wolf O, Lange A, Cooper JE, Frölich K (2000) Necrobacillosis in free-living male European bison in Poland. Journal of Wildlife Diseases 36(2):248-256. https://doi.org/10.7589/0090-3558-36.2.248

Karbowiak G, et al. (2014a) The parasitic fauna of the European bison (Bison bonasus) (Linnaeus, 1758) and their impact on the conservation. Part 1 The summarising list of parasites noted. Acta Parasitologica 59(3):363-371. https://doi.org/10.2478/ s11686-014-0252-0

Karbowiak G, et al. (2014) The parasitic fauna of the European bison (Bison bonasus) (Linnaeus, 1758) and their impact on the conservation. Part 2 The structure and changes over time. Acta Parasitologica 59(3):372-379. https://doi.org/10.2478/s11686014-0253-z

Kołodziej-Sobocińska M, Demiaszkiewicz AW, Lachowicz J, Borowik T, Kowalczyk R (2016a) Influence of management and biological factors on the parasitic invasions in the wild-spread of blood-sucking nematode Ashworthius sidemi in European bison (Bison bonasus). International Journal for Parasitology: Parasites and Wildlife 5(3):286-294. DOI:http://dx.doi.org/10.1016/j.ijp paw.2016.09.005

Kołodziej-Sobocińska M, Demiaszkiewicz AW, Pyziel AM, Marczuk B, Kowalczyk R (2016) Does the blood-sucking nematode Ashworthius sidemi (Trichostrongylidae) cause deterioration of blood parameters in European bison (Bison bonasus)? European Journal of Wildlife Research 62:781-785. https://doi.org/10.1007/ s10344-016-1037-6

Kołodziej-Sobocińska M, Pyziel AM, Demiaszkiewicz AW, Borowik T, Kowalczyk R (2016c) Pattern of parasite egg shedding by European bison (Bison bonasus) in the Białowieża Primeval Forest, Poland. Mammal Research 61(3):179-186. https://doi. org/10.1007/s13364-016-0270-4

Krasińska M, Krasiński ZA (2013) European bison. The Nature Monograph., 2nd ed., Berlin Heudelberg: Springer-Verlag

Krzysiak MK, Demiaszkiewicz AW, Pyziel AM, Larska M (2015) Parasitological monitoring in the European Bison Breeding Center of Białowieża National Park. Medycyna Weterynaryjna 71(12):791-795 
Kuemmerle T, Radeloff VC, Perzanowski K, Kozlo P, Sipko T, Khoyetskyy P, Bashta AT, Chikurova E, Parnikoza I, Baskin L, Angelstam P, Waller DM (2011) Predicting potential European bison habitat across its former range. Ecological Applications 21(3):830-843. https://doi.org/10.1890/10-0073.1

Mathews F, Moro D, Strachan R, Gelling M, Buller N (2006) Health surveillance in wildlife reintroductions. Biological Conservation 131(2):338-347. http://dx.doi.org/10.1016/j.biocon. 2006.04.011

May RM (1988) Conservation and Disease. Conservation Biology 2(1):28-30

Pucek Z, Belousova IP, Krasińska M, Krasiński ZA, Olech W (2004) European bison. Status Survey and Conservation Action Plan. IUCN/SSB Bison Specialist Group IUCN, ix + 54., Gland, Switzerland: Cambridge

Pyziel AM, Kowalczyk R, Demiaszkiewicz AW (2011) The Annual cycle of shedding eimeria oocysts by European Bison (Bison bonasus) in the Białowieża Primeval Forest, Poland. Journal of Parasitology 97(4):737-739. https://doi.org/10.1645/ge-2567.1

Raczyński J (2015) European Bison Pedigree Book 2014, Białowieża: Białowieża National Park

Radwan J, Demiaszkiewicz A W, Kowalczyk R, Lachowicz J, Kawałko A, Wójcik JM, Pyziel AM, Babik W (2010) An evaluation of two potential risk factors, MHC diversity and host density, for infection by an invasive nematode Ashworthius sidemi in endangered
European bison (Bison bonasus). Biological Conservation 143(9):2049-2053. https://doi.org/10.1016/j.biocon.2010.05.012

Schmidt-Posthaus $\mathrm{H}$, Breitenmoser-Wursten C, Posthaus $\mathrm{H}$, Bacciarini L, Breitenmoser U (2002) Causes of mortality in reintroduced Eurasian lynx in Switzerland. Journal of Wildlife Diseases 38(1):84-92

Scott ME (1988) The impact of infection and disease on animal populations: implications for conservation biology. Conservation Biology 2(1):40-56. https://doi.org/10.1111/j.1523-1739. 1988.tb00334.x

Tear TH, Scott JM, Hayward PH, Griffith B (1993) Status and prospects for success of the endangered species act - a look at recovery plans. Science 262(5136):976-977. https://doi.org/10. $1126 /$ science.262.5136.976

Tokarska M, Pertoldi C, Kowalczyk R, Perzanowski K (2011) Genetic status of the European bison Bison bonasus after extinction in the wild and subsequent recovery. Mammal Review 41(2):151162. https://doi.org/10.1111/j.1365-2907.2010.00178.x

Viggers KL, Lindenmayer DB, Spratt DM (1993) The importance of disease in reintroduction programs. Wildlife Research 20(5):687-698. https://doi.org/10.1071/wr9930687

Wakelin D (1978) Genetic control of susceptibility and resistance to parasitic infection. In: Advances in Parasitology, Lumsden WHR, Baker JR (editors), vol Volume 16. Academic Press, pp 219-308 